\title{
Bioethanol Production via Syngas Fermentation
}

\author{
Irika Anggraini ${ }^{1}$, Made Tri Ari Penia Kresnowati ${ }^{*}$, Ronny Purwadi $^{1}$, and Tjandra Setiadi ${ }^{1,2}$ \\ ${ }^{1}$ Department of Chemical Engineering, Faculty of Industrial Technology Institut Teknologi Bandung, Jl. Ganeesa 10, Bandung 40132, \\ Indonesia \\ ${ }^{2}$ Centre for Environmental Studies (PSLH), Institut Teknologi Bandung, Jl. Sangkuriang 42 A, Bandung 40135, Indonesia
}

\begin{abstract}
Bioconversion of C-1 carbon in syngas through microbial fermentation presents a huge potential to be further explored for ethanol production. Syngas can be obtained from the gasification of lignocellulosic biomass, by which most of carbon content of the biomass was converted into $\mathrm{CO}$ and $\mathrm{CO}_{2}$. These gases could be further utilized by carbon-fixing microorganism such as Clostridium sp. to produce ethanol as the end product. In order to obtain an optimum process, a robust and high performance strain is required and thus high ethanol yield as the main product can be expected. In this study, series of batch fermentation was carried out to select high performance strains for ethanol production. Bottle serum fermentations were performed using CO-gas as the sole carbon source to evaluate the potential of some Clostridia species such as Clostridium ljungdahlii, C. ragsdalei, and C. carboxidovorans in producing ethanol at various concentration of yeast extract as the organic nitrogen source, salt concentration, and buffer composition. Strain with the highest ethanol production in the optimum media will be further utilized in the upscale fermentation.
\end{abstract}

\section{Introduction}

Syngas bioconversion for ethanol production is one of tools to utilize completely all carbon content of lignocellulosic biomass. Not limited only from gasified lignocellulose, industrial waste gas rich of $\mathrm{CO}, \mathrm{CO}_{2}$, and $\mathrm{H}_{2}$ or gas waste from municipal solid waste and agriculture and forestry residue can be utilized as the gaseous substrate to produce biofuels and other value added chemicals [1-4]. The conversion process is able to be undertaken by two routes, thermochemical route by Fischer Trop reaction (metal catalyst base process) and biochemical route through fermentation by employing acetogenic bacteria [1,5]. However, compared to other approaches syngas fermentation offers many advantages such as tolerance level of bacteria to several impurities in syngas, bacteria ability in consuming flexible syngas compositions, the applied low temperature and pressure, high specificity of the product, and bacteria ability to use $\mathrm{CO}_{2}$ in the fermentation process which can be toxic for metal catalyst in thermochemical route [1,5-8].

Some strains of Clostridium $s p$. that have been studied capable of converting syngas into solvent products are Clostridium ljungdahlii, $C$. carbodixovorans, C. ragsdalei, and C. autoethanogenum (carboxydotrophic species) [4,9]. These species utilize reductive Acetyl-CoA pathway or Wood-Ljungdahl pathway (WLP) during their growth in the presence of $\mathrm{CO} / \mathrm{CO}_{2} / \mathrm{H}_{2}$ and generate acetyl-CoA as the key intermediate product for a diverse metabolites production [10]. These strains are categorized into mesophiles as their optimum growth temperature is between $37^{\circ} \mathrm{C}$ and $40^{\circ} \mathrm{C}$.

C. ljungdahlii and $C$. autoethanogenum are the common model microorganism for basic research and commercial application [4]. From a comparison study of syngas fermentation between $C$. ijungdahlii and $C$. autoethanogenum strains, C. ljungdahlii is revealed to be a more superior ethanol producer than $C$. autoethanogenum by ethanol titter produced in low $\mathrm{pH}$ condition [11]. Furthermore, some studies also confirm that $C$. autoethanogenum is a low productivity bacteria in ethanol production compared to other carboxidotrophic strains of Clostridium sp. despite its genetic modified strain has been developed for ethanol commercial scale production by LanzaTech [1,12-14]. C. ragsdaleii and $C$. carbodixovorans are the recent isolated strains which their potential are still in the exploration $[15,16]$. C. carbodixovorans is also a natural butanol producer, beside producing ethanol and hexanol [17]. Meanwhile, capability of $C$. ragsdaleii has been widely studied to produce ethanol under growth on low cost feedstock such as corn steep liquor and cotton seed extract as yeast extract and vitamins substitution in the cultivation and fermentation process [18-20]. Another study also revealed capabilities of $C$. autoethanogenum, C. ljungdahli, and $C$. ragsdalei to produce 2,3butanediol as another solvent product [21].

There are several important process parameters that may affect the ethanol yield of syngas fermentation $[5,8,22]$. Low solubility of $\mathrm{CO}$ and $\mathrm{H}_{2}$ which affects to gas to liquid mass transfer is known as the major bottleneck. Other parameters such as gas composition,

\footnotetext{
${ }^{*}$ Corresponding author: kresnowati@che.itb.ac.id
} 
$\mathrm{pH}$, temperature, gas pressure, media buffer and nutrient composition may also significantly influence ethanol to acetate ratio. In case of optimum $\mathrm{pH}$, many studies revealed maintaining fermentation medium at $\mathrm{pH} 4.5$ would enhance ethanol production since the condition promotes to solventogenic phase which associated with non-growth or resting cells phase [23]. Metabolically, acetic acid as the product that follows exponential cell growth will be consumed by the cell to produce ethanol as a counteract of internal $\mathrm{pH}$ drop caused by the accumulation of undissociated acid [24]. The influence of medium $\mathrm{pH}$ has also been studied in ABE fermentation for butanol production which suggested optimum $\mathrm{pH}$ for solventogenic Clostridium sp. to be in the range of 4.5-5.5 [25]. To give a better $\mathrm{pH}$ control in its optimum range, morpholinoethane sulfonic acid (MES) buffer is commonly utilized [20]. However, some studies revealed the absence of MES gave a positive influence to earlier ethanol production driven by a quick drop of medium $\mathrm{pH}$ below 5.0 [18,26]. Furthermore, the removal of MES buffer offered a low cost process in upscale fermentation since MES counts for approximately $97 \%$ of the standard media cost [20].

The objective of this study is to evaluate the performance of 3 Clostridium strains: C. ljungdahlii, $C$. ragsdalei (P11), and $C$. carbodixovorans $(\mathrm{P} 7)$ in converting $\mathrm{C} 1$-gaseous compound (CO) into ethanol as the attempt of selection of robust and high performance candidate strain for ethanol production from syngas. As were suggested in many studies that nutrient-limited condition is favorable for ethanol production [18,23], a series of bottle serum fermentations will be performed in media with varied concentration of yeast extract $(0.5 \mathrm{~g} / \mathrm{L}$ and $1 \mathrm{~g} / \mathrm{L})$, mineral, and MES buffer $(5 \mathrm{~g} / \mathrm{L}$ and $10 \mathrm{~g} / \mathrm{L})$. Strain with the highest maximum ethanol production in its favorable condition will be employed in the upscale fermentation. Base composition of fermentation medium is also expected as the output of this preliminary study.

\section{Materials and methods}

\subsection{Microorganism, media, and inoculum Preparation}

C. ljungdahlii DSM 13258, C. carbodixovorans DSM 15243 was acquired from Deutsche Sammlung von Mikroorganismen und Zellkulturen $\mathrm{GmbH}$ culture collection (Braunschweig, Germany) in freeze dried culture while $C$. ragsdalei DSM 15248 in active growing culture. The cultures were activated anaerobically in 10 $\mathrm{mL}$ growth medium with $5 \mathrm{~g} / \mathrm{L}$ fructose as carbon source and further cultivated in $50 \mathrm{~mL}$ liquid medium.

Growth media of $C$. carbodixovorans (P7) and $C$. ragsdaleii (P11) were prepared with the same composition of media components based on Rajagolapan [3]. Growth media of P7 and P11 contained (per L) 25$30 \mathrm{~mL}$ mineral solution, $10 \mathrm{~mL}$ trace metal solution, $10 \mathrm{~g}$ 2-mercaptoethanosulfonic acid sodium salt (MESNA), 1 $\mathrm{g}$ yeast extract, $0.1 \mathrm{~mL}$ resazurin $0.1 \% \mathrm{w} / \mathrm{v}$ solution as redox indicator, $10 \mathrm{~mL}$ vitamin solutions and $5 \mathrm{~mL}$ cystein- $\mathrm{HCl} 4 \% \mathrm{w} / \mathrm{v}$ solution as reducing agent (added after medium sterilized).

Growth media of $C$. ljungdahlii was prepared based on DSMZ medium 879 [27]. Medium contained (per L) mineral components that were straightly mixed with other components such as $10 \mathrm{~mL}$ trace element, $10 \mathrm{~g}$ MES, $1 \mathrm{~g}$ yeast extract, and $0.1 \mathrm{~mL}$ resazurin $0.1 \% \mathrm{w} / \mathrm{v}$ solution, except $10 \mathrm{~mL}$ vitamin solution and $5 \mathrm{~mL}$ cysteine $4 \% \mathrm{w} / \mathrm{v}$ added after medium sterilized. Prior to media sterilization at $121^{\circ} \mathrm{C}$ for $15 \mathrm{~min}$, all media in bottle serums equipped with butyl rubber stoppers and aluminum sealed were purged with ultra-high purity $\mathrm{N}_{2}$ gas. After sterilization, vitamin and cysteine were added into media then $\mathrm{pH}$ of all fresh media were adjusted to 6.0 using $2 \mathrm{M} \mathrm{NaOH}$ and $2 \mathrm{M} \mathrm{HCl}$ prior to inoculation in anaerobic chamber $\left(\mathrm{N}_{2}\right.$ atmospheric). Incubation was at $37^{\circ} \mathrm{C}$ for 7 days without agitation before transferred to other fresh media for subculturing. After three passages of subculture in fructose media, carbon source was replaced by $\mathrm{CO}$ gas. Medium with gaseous substrate was prepared by purging fresh medium with $99 \% \mathrm{CO}$-gas at pressure $2 \mathrm{~atm}$ (abs) for $1 \mathrm{~min}$ prior to inoculation.

\subsection{Bottle batch fermentation with variation in MES buffer, yeast extract, and salt concentrations}

Batch fermentation using $\mathrm{CO}$ gas as the sole carbon source was carried out in $100 \mathrm{~mL}$ bottle serum containing $50 \mathrm{~mL}$ liquid medium. Fermentation medium of P7 and P11 was prepared based on standard basal medium with 100x salt concentration of growth medium in mineral stock solution and higher concentration of trace elements than in the growth media to promote high ethanol production (Ni, W, and $\mathrm{Se}$ ) [16]. Standard fermentation medium of $C$. ljungdahlii was prepared in similar concentration of mineral components with growth medium [27]. To study the effect of salt concentration in improving ethanol production, modified medium of P7 and P11 was prepared with dilute salt concentration (referred as modified " $10 \mathrm{x}$ and $20 \mathrm{x}$ $\mathrm{NH}_{4} \mathrm{Cl}$ "), while modified medium of $C$. ljungdahlii was in $1.5 \mathrm{x}$ and $3 \mathrm{x}$ higher salt concentrations (referred as modified media " $1.5 \mathrm{x} \mathrm{NH}_{4} \mathrm{Cl}$ " and " $3 \mathrm{x} \mathrm{NH}_{4} \mathrm{Cl}$ ") (Table 1). All modified fermentation media of the three strains were prepared using reduced concentration of yeast extract $(0.5 \mathrm{~g} / \mathrm{L})$ and buffer MES $(5 \mathrm{~g} / \mathrm{L})$.

Before inoculated with $10 \%$ seed culture grown in the growth media, $\mathrm{pH}$ of each fresh medium was adjusted at optimum $\mathrm{pH}$ growth 6.0 and purged with $\mathrm{CO}$ at $2 \mathrm{~atm}$ (abs) for $1 \mathrm{~min}$. Inoculated media was incubated at $37^{\circ} \mathrm{C}$ in anaerobic chamber with agitation at 190-200 rpm for 24 days. CO-gas in bottle headspace was refilled every $24 \mathrm{~h}$. Two milliliters of fermentation broth were withdrawn at Day 7, Day 11, Day 18 for optical density $\left(\mathrm{OD}_{600}\right)$ measurement and fermentation product analysis. All experiments were carried out in duplicate.

\subsection{Biomass and metabolite product analysis}


Cell (biomass) density was determined by optical density measurement using UV-Vis Spectrophotometer at 600 $\mathrm{nm}\left(\mathrm{OD}_{600}\right)$. Ethanol and acetate concentrations as end metabolite products were determined by HPLC (Waters, Milford, MA, USA) with an Aminex HPX 87H column (Bio-Rad). HPLC buffer was $5 \mathrm{mM}$ sulfuric acid in water and the flow rate was $0.6 \mathrm{~mL} / \mathrm{min}$. The concentration of metabolites is calculated using external standard of ethanol and acetate calibration curve.

Table 1. Salt composition of modified fermentation medium $(\mathrm{g} / \mathrm{L})$

\begin{tabular}{|l|l|l|l|l|l|l|}
\hline \multirow{3}{*}{$\begin{array}{c}\text { Compo } \\
\text { nent }\end{array}$} & \multicolumn{2}{|c|}{$\begin{array}{c}\text { Standard } \\
\text { fermentation } \\
\text { media }\end{array}$} & \multicolumn{2}{c|}{$\begin{array}{c}\text { Modified media } \\
\text { P7 and P11 }\end{array}$} & \multicolumn{2}{|c|}{$\begin{array}{c}\text { Modified } \\
\text { media } \\
\text { (C.ljungdahlii }\end{array}$} \\
\cline { 2 - 8 } & $\begin{array}{c}\mathrm{P} 7 \\
\text { and } \\
\mathrm{P} 11\end{array}$ & $\begin{array}{c}\text { C.jungdahli } \\
i\end{array}$ & $\begin{array}{c}\text { C. } \\
\mathrm{NH}_{4} \mathrm{C} \\
1\end{array}$ & $\begin{array}{c}20 \mathrm{x} \\
\mathrm{NH}_{4} \mathrm{Cl}\end{array}$ & $\begin{array}{c}1.5 \mathrm{x} \\
\mathrm{NH}_{4} \\
\mathrm{Cl}\end{array}$ & $\begin{array}{c}3 \mathrm{x} \\
\mathrm{NH}_{4} \\
\mathrm{Cl}\end{array}$ \\
\hline $\mathrm{NH}_{4} \mathrm{Cl}$ & 3 & 1 & 0.3 & 0.6 & 1.5 & 3 \\
\hline $\mathrm{NaCl}$ & 2.4 & 0.8 & 0.24 & 0.48 & 1.2 & 2.4 \\
\hline $\mathrm{KCl}$ & 0.3 & 0.1 & 0.03 & 0.06 & 0.15 & 0.3 \\
\hline $\begin{array}{l}\mathrm{KH}_{2} \mathrm{PO} \\
4\end{array}$ & 0.3 & 0.1 & 0.03 & 0.06 & 0.15 & 0.3 \\
\hline $\mathrm{MgSO}_{4}$ & 0.6 & 0.2 & 0.06 & 0.12 & 0.3 & 0.6 \\
\hline $\mathrm{CaCl}_{2}$ & 0.12 & 0.02 & 0.012 & 0.024 & 0.03 & 0.12 \\
\hline
\end{tabular}

\section{Results and Discussion}

\subsection{C. carbodixovorans (P7) and C. ragsdalei (P11)}

\subsubsection{Standard growth medium and medium with yeast extract and MES reduction}

The effect of media on P7 and P11 cell growth and the production of ethanol and acetate are summarized in Fig 1.

In growth media, standard composition of yeast extract $(1 \mathrm{~g} / \mathrm{L})$ as organic $\mathrm{N}$ source and MES buffer (10 $\mathrm{g} / \mathrm{L}$ ) were applied to promote high cell density of growing culture. By using $\mathrm{CO}$ as the sole carbon source, P11 was able to reach final $\mathrm{OD}_{600} 0.2$ after 11 days of incubation and had a stationary phase until Day 18, while $\mathrm{P} 7$ final $\mathrm{OD}_{600}$ only slightly exceeded 0.1 until Day 18. In media with reduced yeast extract and buffer MES concentration $(0.5 \mathrm{~g} / \mathrm{L}$ and $5 \mathrm{~g} / \mathrm{L})$, lower cell densities of P11 during exponential growth (Day 7 - Day 11) were observed in correspond to reduced yeast in medium while P7 could not maintain its cell viability until day 18.

Growth of P11 and P7 in standard growth media was accompanied by ethanol and acetate production (Fig 1). As observed, ethanol and acetate were started to be produced at Day 7 (beginning of exponential cell growth) and continued to increase until Day 18 (data not shown). Final concentration of ethanol at Day 18 reached $0.2 \mathrm{~g} / \mathrm{L}$ and $0.1 \mathrm{~g} / \mathrm{L}$, in $\mathrm{P} 11$ and $\mathrm{P} 7$, respectively. In P11, significant cell growth in standard medium was also followed by significant ethanol production. In P7, however, acetate accumulation as associated growth product dominated cell metabolite production.

On the other hand, the cell growth and ethanol production were observed to be lower in growth media with yeast and MES reduction. In P11, low ethanol production could only reach $0.12 \mathrm{~g} / \mathrm{L}$ at Day 18 . Interestingly, high concentration of acetate was observed.

The reduction of yeast extract specifically in particular inhibited the growth of $\mathrm{P} 7$ as its cell density barely reached final $\mathrm{OD}_{600} 0.1$ throughout the cultivation. Further, no increase in ethanol and acetate production was observed.

Overall, the use of standard media containing richnutrient is suitable for ethanol production by P11 in which we observed significant cell growth that was accompanied by high ethanol titter. Media with reduction of yeast and MES is not suitable for ethanol production.

A

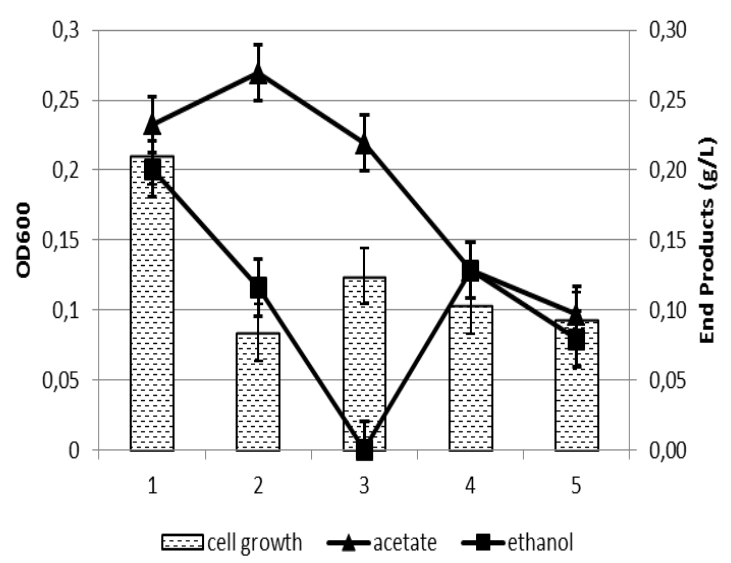

B

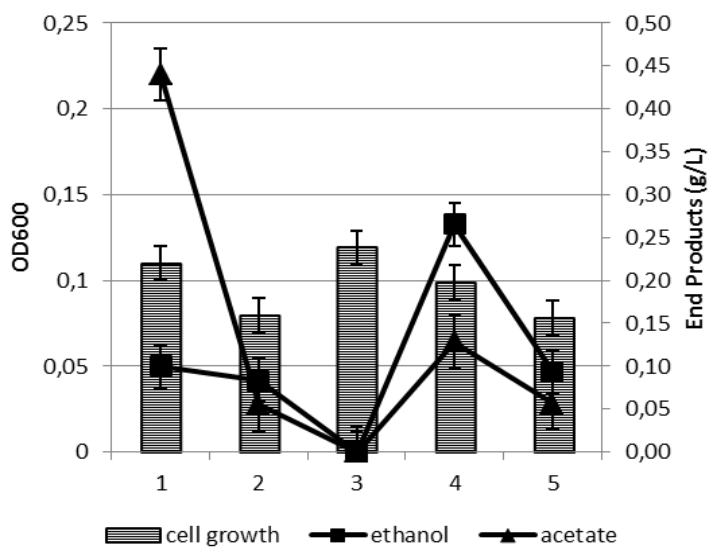

Fig 1. Growth, ethanol, and acetate profile of P11 (A) and P7 (B) after 18 days of incubation in (1) standard growth medium, (2) reduced growth medium, (3)standard fermentation medium, (4) modified $20 \mathrm{xNH}_{4} \mathrm{Cl}$ medium, (5) modified $10 \mathrm{x}$ $\mathrm{NH}_{4} \mathrm{Cl}$ medium 


\subsubsection{Fermentation medium with standard and modified salt concentration}

Standard fermentation media of P7 and P11 contained 100x salt concentration higher than in the growth media since yeast extract as organic $\mathrm{N}$ source was replaced by $\mathrm{NH}_{4} \mathrm{Cl}$. As were suggested in many studies, nutrientlimited environmental condition induced cell stress condition that initiated resting cell phase which associated with solvent production [23]. Some studies also suggest removal of MES buffer as its absence leads to earlier ethanol production due to a quick drop of medium $\mathrm{pH}$ as the result of acetic acid accumulation [26]. In this study, yeast extract and buffer MES were not totally removed but reduced to $0.5 \mathrm{~g} / \mathrm{L}$ and $5 \mathrm{~g} / \mathrm{l}$, respectively.

Compared to the cell growth in rich-nutrient of growth media, a suppressed cell growth of P11 was observed throughout the fermentation. Acetate was detected in comparable concentration as in the growth media, whereas no ethanol was detected. On the other hand, P7 was observed to grow better in this media. However, neither ethanol nor acetate was found in the fermentation broth (Fig 1). It presumed that the presence of excess $\mathrm{NH}_{4} \mathrm{Cl}$ as inorganic $\mathrm{N}$ source significantly drives cell metabolism to utilize limited $\mathrm{CO}$-gaseous substrate dissolved in media for biomass formation. Thus, it is possible none of significant metabolites produced in P7 and P11 although the fermentation carried out in standard fermentation media.

In other study of P7 batch bottle fermentation which conducted using the same composition of standard media and sole CO-gas supply, maximum biomass concentration $(0.13 \mathrm{~g} / \mathrm{L})$ had been reached after the first $30 \mathrm{~h}$. Maximum ethanol concentration and acetic acid were able to reach $0.48 \mathrm{~g} / \mathrm{L}$ and $0.89 \mathrm{~g} / \mathrm{L}$, respectively, in 11 days of fermentation [28].

As comparison study, fermentation was also conducted using modified media with more dilute salt concentrations (10x and $20 \mathrm{x} \mathrm{NH}_{4} \mathrm{Cl}$ of growth medium). Results of the fermentation revealed suppressed cell growth of both P7 and P11 as observed in the reduced growth medium (Fig 1). As observed in both strains, ethanol and acetate was started to be produced at Day 11 when the cell growth started to descend (data not shown). Growth of $\mathrm{P} 7$ in medium $20 \mathrm{x} \mathrm{NH} \mathrm{NH}_{4} \mathrm{Cl}$ was accompanied by high ethanol production which the titer was able to reach the highest value as recorded throughout this study, while the titter in medium 10x $\mathrm{NH}_{4} \mathrm{Cl}$ was insignificant (Fig 1).

The result of improved ethanol production in $\mathrm{P} 7$ with 20x $\mathrm{NH}_{4} \mathrm{Cl}$ medium suggested the bacteria favorable condition for ethanol production. Other P7 study in bottle batch fermentation using formulated minimal media even produced a higher ethanol titter $(3.25 \mathrm{~g} / \mathrm{L})$ which was also as the effect of gas composition which contained $\mathrm{CO}$ and $\mathrm{H}_{2}$ as a simultaneous electron donor [17]. As observed in this study, unlike P11, acetate production in $\mathrm{P} 7$ was significantly suppressed. Based on the overall results of $\mathrm{P} 7$ cell growth, the cell density had never been exceeded P11 cell growth, thus it could be a reason why acetate accumulation was not observed.
Acetate accumulation in bottle serum fermentation is often linked to high density of biomass that could lead to inhibition of solvent production due to a quick drop of $\mathrm{pH}$ or "acid crash" [28]. In bioreactor fermentation, this problem can be avoided by applying $\mathrm{pH}$ regulation after medium $\mathrm{pH}$ starts to drop [28].

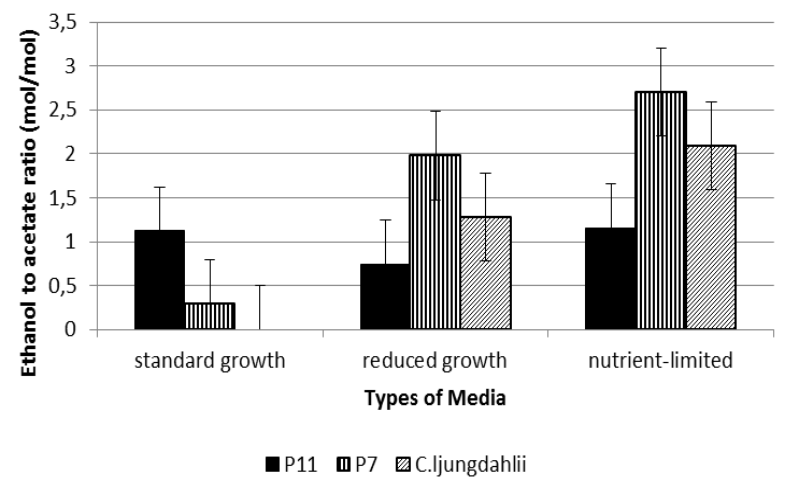

Fig 2. Ethanol to acetate molar ratio of $\mathrm{P} 11, \mathrm{P} 7$, and $C$. ljungdahlii in standar growth media, reduced growth media, and nutrient-limited media after 18 days incubation

In P11 fermentation, ethanol titter reached in both media was not significantly different with dominating acetate over ethanol concentration. However, as the cell density dropped at Day 24, ethanol concentration gradually increased in medium $20 \mathrm{x} \mathrm{NH}_{4} \mathrm{Cl}(0.06 \mathrm{~g} / \mathrm{L}$ to $0.15 \mathrm{~g} / \mathrm{L}$ ) and followed by increasing ethanol to acetate ratio (data not shown). Overall, stress condition due to the presence of higher salt concentration, unlike P7, did not give positive influence to the enhancement of ethanol production although cell growth was found suppressed. As seen from the result of study in yeast and MES reduction, ethanol production by $\mathrm{P} 11$ favors more standard growth medium without excess salt concentration indicated by highest ethanol titer throughout this study although ethanol to acetate molar ratio in average was at the lowest if compared to $C$. ljungdahlii and C. carbodixovorans (Fig 2). In other study of bottle serum fermentation by P11, nutrientlimited media also gave insignificant effect to improved ethanol production [18]. Based on references, so far highest ethanol concentration $(1.7 \mathrm{~g} / \mathrm{L})$ was reached when P11 grown in $20 \mathrm{~g} / \mathrm{L}$ Corn Steep Liquor (CSL) as low-cost media which also containing $0.32 \mathrm{~g} / \mathrm{L}$ glucose [19].

By comparing highest ethanol titter and ethanol to acetate molar ratio achieved in each of the two strain's favorable condition, P7 is more superior as ethanol producer than P11 (Fig 2). In addition, P7 fermentation is also able to be performed in minimal media $(20 \mathrm{x}$ $\mathrm{NH}_{4} \mathrm{Cl}$ ) with reduction use of yeast and MES buffer which can be the advantage for a low-cost syngas fermentation. 


\subsection{C. ljungdahlii}

\subsubsection{Standard growth medium and medium with yeast extract and MES reduction}

The effect of media on $C$ ljungdahlii cell growth and the production of ethanol and acetate are summarized in Fig 3.

In standard growth medium, $C$. ljungdahlii growth reached final $\mathrm{OD}_{600}$ of 0.2 after 11 days of incubation and entered stationary growth until Day 18 . Cell growth was solely followed by high acetate production $(0.63$ $\mathrm{g} / \mathrm{L})$ as the associated growth product. In media with yeast and MES reduction, a suppressed cell growth was accompanied by ethanol production. At Day 11, ethanol concentration reached $0.18 \mathrm{~g} / \mathrm{L}$ and continued to increase to $0.21 \mathrm{~g} / \mathrm{L}$ at Day 18 .

\subsubsection{Fermentation medium with standard and modified salt concentration}

Improved ethanol production was demonstrated in fermentation using $1.5 \mathrm{x} \quad \mathrm{NH}_{4} \mathrm{Cl}$ of standard salt concentration (Fig 3). In this medium, cells were unable to maintain high cell density as suppressed cell growth was shown as growth in reduced growth medium. Ethanol titer achieved $0.41 \mathrm{~g} / \mathrm{L}$ with ethanol to acetate molar ratio 2.09 at Day 18. As shown on Fig 2, in spite of lower ethanol to acetate ratio than $\mathrm{P} 7$, C. ljungdahlii in its favorable condition was able to produce higher ethanol titer. Compared to P7, more acetate was produced by $C$. ljungdahlii yet higher ethanol production was also promoted although the production as the expense of acetate was not observed. Based on references, $C$. ljungdahlii is known to be a superior ethanol production strain even in nutrient-limited media which has been studied to also gave positive effect to the enhancement of ethanol production $[29,30]$.

In medium $3 \times \mathrm{NH}_{4} \mathrm{Cl}, C$. ljungdahlii showed cell intolerance to high salt concentration, whereas the same salt concentration also used in standard fermentation medium of P7 and P11 (Table 1). It was indicated by a significant drop of cell density after 15 days incubation which was also the lowest final $\mathrm{OD}_{600}$ value of the strain throughout this study. The suppressed cell growth was followed by acetate formation yet no ethanol being produced. Too high salt concentrations implicated to unfavorable condition for cells growth and ethanol production. In other study, it was revealed that the presence of $4 \mathrm{x}$ salt concentration in medium would implicate to rapid loss of $C$. ljungdahlii cell viability due to bacteria salt stress [31]. Effect of $\mathrm{C} / \mathrm{N}$ ratio from carbon and nitrogen supply in medium also had influence to $C$. ljungdahlii metabolism in producing metabolite products which can give result to neither ethanol or acetate production as observed in P7 and P11 standard fermentation [23].

\section{$3.3 \mathrm{CO}$ as sole carbon source}

Low density of cell grown on $\mathrm{CO}$ as gaseous substrate was possible as the effect of limited CO supply in bottle serum fermentation. CO-gas mass transfer is also known as the key factor of fermentation performance $[32,33]$. In general, all the three strains only could reach maximum $\mathrm{OD}_{600}$ value 0.2 when being grown on $\mathrm{CO}$, while their cultivation using fructose as carbon source could reach $\mathrm{OD}_{600}$ 0.4-0.6 after 7 days incubation (data not shown). Cell growth of the three strains in fructose were also followed with ethanol and acetate production in which acetate accumulation as associated growth product was observed in all strains growing culture (data not shown). However, ethanol titter was insignificant if compared to ethanol titer that achieved in fermentation with favorable condition using $\mathrm{CO}$ as sole $\mathrm{C}$-source.

To get high density of cell, cultivation and fermentation can be carried out separately by performing two stage fermentation system using rich medium for cell growth and minimal medium for ethanol production using a continuous suppy of CO-gas [31]. This system has been proved to enhance ethanol production if compared to the performance of single stage fermentation.

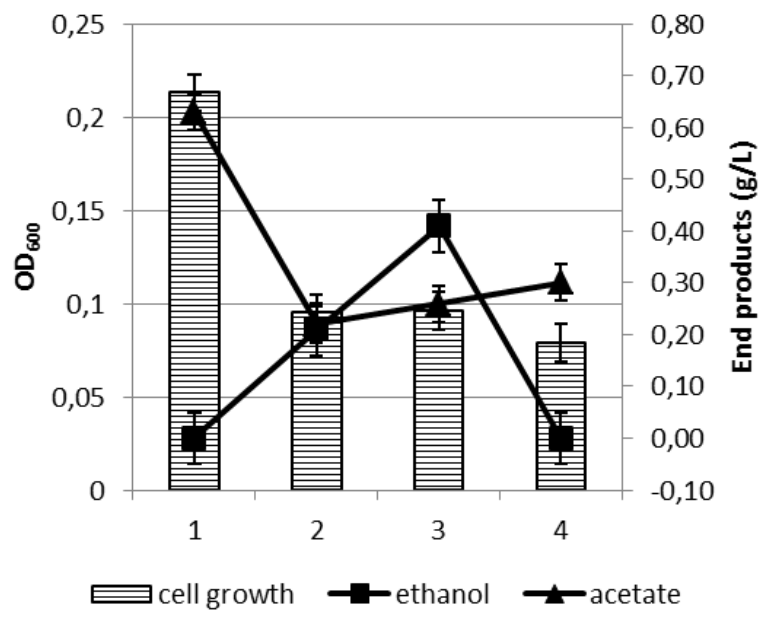

Fig 3. Growth, ethanol, and acetate profile of C. ljungdahlii after 18 days of incubation in (1) standard growth medium, (2) reduced growth medium, (3) modified medium $1.5 \mathrm{x} \mathrm{NH}_{4} \mathrm{Cl}$, (4) modified medium $3 \mathrm{x} \mathrm{NH}_{4} \mathrm{Cl}$

\section{Conclusion}

From this study, growth and metabolic profile of the three strains [C. ljungdahlii, C. carbodixovorans (P7), and $C$. ragsdalei $(\mathrm{P} 11)]$ in standard and nutrient-limited media were able to identify favorable condition of fermentation for each strain. Reduction of yeast extract and buffer MES affected to ethanol production in $C$. ljungdahlii while an appropriate amount of salt concentration used in the modified media of $C$. ljungdahlii and P7 promoted higher ethanol titer. Ethanol 
production in P11 was favorable to be conducted in standard growth medium.

As shown by the highest maximum ethanol titter achieved in its favorable condition, $C$. ljungdahlii is a superior ethanol producer over the two other strains. The composition of modified medium $1.5 \mathrm{x} \mathrm{NH}_{4} \mathrm{Cl}$ can be used as base information for upscale fermentation.

This study is part of SATREPS Program (Science and Technology Research Partnership for Sustainable Development), research collaboration between Gunma University, Japan and Bandung Institute of Technology, Indonesia and funded by Japan International Corporation Agency.

\section{Reference}

1. M. Kopke, C. Mihalcea, J.C. Bromley, S.D. Simpson, Curr. Opin. Biotechnol. 22, 320-325 (2011).

2. P. Durre, B.J. Eikmanns, Curr. Opin. Biotechnol. 35, 63-72 (2015).

3. S. Rajagopalan, R.P. Datar, R.S. Lewis, Biomass and Bioenergy, 23, 487-493 (2002).

4. B. Molitor, H. Richter, M.E. Martin, R.O. Jensen, A. Juminaga, C. Mihalcea, L.T. Angenent, Bioresour. Technol. 215, 386-396 (2016).

5. F.R. Bengelsdorf, M. Straub, P. Dürre, Environ. Technol. 34, 37-41 (2013).

6. D. $\mathrm{Xu}$, D.R. Tree, R.S. Lewis, Biomass and Bioenergy 35, 2690-2696 (2011).

7. M.R. Wilkins, H.K. Atiyeh, Curr. Opin. Biotechnol. 22, 326-330 (2011).

8. P.C. Munasinghe, S.K. Khanal, Bioresour. Technol. 10, 5013-5022 (2010).

9. D. Kennes, N. Abubackar, M. Diaz, C. Veiga, C. Kennes, J Chem Technol Biotechno 91, 304-317 (2015).

10. S.W. Ragsdale, E. Pierce, Biochim Biophys 1784, 1873-1898 (2009).

11. M. E. Martin, H. Richter, S. Saha, L.T. Angenent, Biotechnology 113, 531-539 (2016).

12. J. Abrini, H. Naveau, E. Nyns, Arch. Microbiol. 161, 345-351 (1994).

13. H. N. Abubackar, M.C. Veiga, C. Kennes, Bioresour. Technol. 186, 122-127 (2015).

14. Y. Guo, J. Xu, Y. Zhang, H. Xu, Z. Yuan, D. Li, Bioresour. Technol. 101, 8784-8789 (2010).

15. J. S. Liou, D. L. Balkwill, G. R. Drake, R. S. Tanner, R. S. Tanner, Int. J. Syst. Evol. Microbiol. 55, 2085-2091 (2005).

16. R. L. Huhnke, R.S. Lewis, R. S. Tanner, Isolation and Characterization of Novel Clostridial Species, US007704723B2, (2010).

17. J. R. Phillips, H. K. Atiyeh, R. S. Tanner, J. R. Torres, J. Saxena, M.R. Wilkins, Huhn, Bioresour. Technol. 190, 114-121 (2015).

18. J. Gao, H.K. Atiyeh, J.R. Phillips, M.R. Wilkins, R.L. Huhnke, Bioresour. Technol. 147, 508-515 (2013).

19. P. Maddipati, H.K. Atiyeh, D.D. Bellmer, R.L.
Huhnke, Bioresour. Technol. 102, 6494-6501 (2011).

20. D.K. Kundiyana, R.L. Huhnke, P. Maddipati, H.K. Atiyeh, M.R. Wilkins, Bioresour. Technol. 101, 9673-9680 (2010).

21. M. Kopke, C. Mihalcea, F. Liew, J.H. Tizard, M.S. Ali, J.J. Conolly, B. Al-sinawi, D. Simpson, Appl. Environ. Microbiol. 77, 5467-5475 (2011).

22. M.D. Bredwell, R.M. Worden, Biotechnol. Prog. 14, 31-38 (1998).

23. J.L. Cotter, M.S. Chinn, A.M. Grunden, Bioprocess Biosyst. Eng. 32, 369-380 (2009).

24. F. Monot, J.-M. Engrasser, H. Petitdemange, Appl. Microbiol. Biotechnol. 19, 422-466 (1984).

25. I.S. Maddox, K.C. Schuster, J. Mol. Microbiol. Biotechnol. 2, 95-100 (2000).

26. D.K. Kundiyana, M.R. Wilkins, P. Maddipati, R.L. Huhnke, Bioresour. Technol. 102, 5794-5799 (2011).

27. G. Najafpour, H. Younesi, Enzyme Microb. Technol. 38, 223-228 (2006).

28. Á. Fernández-naveira, H.N. Abubackar, M.C. Veiga, Appl. Microbiol. Biotechnol. 100, 33613370 (2016).

29. J.R. Phillips, K.T. Klasson, E.C. Clausen, J.L. Gaddy, Appl. Biochem. Biotechnol. 39, 0-7 (1993).

30. K.T. Klasson, M.. Ackerson, E.C. Clausen, J.L. Gaddy, Fuel 70, 605-614 (1991).

31. H. Richter, M.E. Martin, L.T. Angenent, 39874000 (2013).

32. P.C. Munasinghe, S.K. Khanal, Biotechnol. Prog. 26, 1616-1621 (2010).

33. M.D. Bredwell, P. Srivastava, R.M. Worden, 834844 (1999). 